\title{
Pengembangan Media Pop Up Book Pada Pembelajaran PKN Di SD
}

\author{
Erica ${ }^{1}$, Sukmawarti ${ }^{2}$ \\ 1,2Universitas Muslim Nusantara Al-Washliyah
}

Corresponding Author: $@$ erikawihelpmenia@gmail.com

\begin{tabular}{ll}
\hline & ABSTRACT \\
& Penelitian ini bertujuan untuk : (1) menghasilkan media pembelajaran Pop \\
Up Book pada pembelajaran PKn materi pancasila untuk siswa Kelas IV \\
UPT SD Negeri 067775 Medan Johor, (2) mengetahui kelayakan media \\
pembelajaran Pop Up Book pada pembelajaran PKn materi pancasila untuk \\
siswa Kelas IV UPT SD Negeri 067775 Medan Johor yang valid dari hasil \\
validasi kelayakan oleh ahli materi, ahli media dan respon guru. \\
Penelitian ini merupakan jenis penelitian Research and Development (R\&D) \\
dengan model 4D yang dikembangkan oleh Thiagarajan (1974) yang \\
mencakup empat langkah yaitu: tahapan define (pendefinisian), design \\
(perancangan), development (pengembangan), disseminate (penyebaran). \\
Tetapi penelitian ini hanya membatasi sampai tiga tahapan saja yaitu \\
hanya sampai tahap development (pengembangan). Subjek dalam \\
penelitian ini adalah validator ahli materi, ahli media dan ahli \\
pembelajaran. Instrumen yang digunakan untuk mengumpulkan data \\
adalah angket. Teknik analisis data yang digunakan yaitu teknik analisis \\
deskriptif kualitatif. Media yang dikembangkan divalidasi oleh satu \\
orang ahli materi, satu orang ahli media dan satu orang guru kelas IV SD. \\
Berdasarkan penilaian hasil validasi oleh ahli materi menghasilkan \\
produk Pop Up Book yang layak digunakan untuk siswa kelas IV SD. \\
Berdasarkan penilaian hasil validasi oleh ahli media menghasilkan \\
produk Pop Up Book yang sangat layak digunakan untuk siswa kelas IV \\
SD dan berdasarkan penilaian hasil validasi ahli pembelajaran \\
menghasilkan produk Pop Up Book yang sangat layak digunakan untuk \\
siswa kelas IV SD. Maka dari data hasil validasi ketiga validator dapat di \\
simpulkan bahwa media Pop Up Book pada pembelajaran PKn materi \\
pancasila di nyatakan valid dan tidak terdapat revisi oleh para ahli, \\
sehingga dinyatakan sangat layak digunakan sebagai bahan ajar dalam \\
pembelajaran. \\
How to cite
\end{tabular}

\section{PENDAHULUAN}

Guru sebagai pendidik dituntut agar mampu mengembangkan media pembelajaran. Media merupakan bagian penting dalam proses pembelajaran untuk mendukung kegiatan pembelajaran yang dirancang sesuai dengan tuntutan kurikulum, karakteristik sarana serta kebutuhan pemecahan masalah 
Ability : Journal of Education and Social Analysis

Volume 2, Issue 4, Oktober 2021

Page : 110-122

belajar, Penggunaan media akan membantu guru dan siswa dalam proses pembelajaran.

Proses pembelajaran yang baik hendaklah terjadi komunikasi dua arah, dimana dalam hal ini guru harus menciptakan kegiatan belajar dengan melibatkan peserta didik. Selain itu guru juga harus membuat peserta didik tertarik untuk mengikuti pembelajaran. Melalui penggunaan media yang tepat akan menciptakan kualitas pembelajaran yang baik, lebih bermakna dan sesuai dengan kebutuhan pembelajaran maka tujuan pembelajaran akan mudah tercapai.

Salah satu mata pelajaran yang terdapat di Sekolah Dasar seperti PKn merupakan mata pelajaran yang mengajarkan bagaimana bentuk perilaku, sikap, watak dan kepribadian yang baik untuk diterapkan oleh siswa di masyarakat. Adapun dengan mempelajari PKn, peserta didik diharapkan untuk cinta kepada sesama makhluk hidup sesuai nilai-nilai Pancasila agar mereka dapat menerapkannya di dalam kehidupan sehari-hari. Selain itu dengan mempelajari PKn, siswa juga diharapkan agar mengetahui pemahaman materi tentang Pancasila yang merangkum bunyi pancasila, gambar lambang dari sila pancasila, makna sila pancasila dan contoh perilaku dalam kehidupan seharihari dari setiap sila pancasila. Pembelajaran dari PKn juga diharapkan dapat membantu siswa untuk memahami dan melaksanakan hak dan kewajiban secara jujur, bertanggung jawab, dan demokratis.

Dalam penggunaan media pembelajaran sangat penting khususnya dalam mengajarkan pada usia Sekolah Dasar yang masih tergolong anak-anak. Menurut Piaget (Sugiarti dan Handayani, 2017: 111) mengenai perkembangan proses belajar siswa, bahwa siswa pada usia 7-11 tahun masih tergolong anakanak yang telah memasuki tahap operasional konkret atau nyata, Pada tahap operasional konkret anak dapat mengembangkan pikiran logis. Sehingga setelah pembelajaran PKn menggunakan media pembelajaran yang dikembangkan dan diberikan pada anak-anak Sekolah Dasar diharapkan agar pembelajaran PKn disekolah dasar dapat disajikan secara menarik, efisien, efektif dan dapat membantu siswa untuk berpikir logis, kritis, kreatif serta dapat beragumentasi dengan benar. Media pembelajaran merupakan perantara atau pengantar pesan dari guru kepada siswa agar mempermudah pendidik dalam menyampaikan materi pembelajaran dan membantu peserta didik dalam memahami materi yang diajarkan, sehingga tujuan pembelajaran dapat tercapai secara maksimal.

Namun pada kenyataannya yang telihat secara umum, mata pelajaran PKn disekolah dasar merupakan mata pelajaran yang cenderung dianggap membosankan serta monoton sehingga peserta didik mengantuk saat pelajaran 
Ability : Journal of Education and Social Analysis

Volume 2, Issue 4, Oktober 2021

Page : 110-122

berlangsung dan siswa juga belum sepenuhnya terlibat secara langsung, seperti halnya yang terjadi pada temuan di magang III yang telah dilaksanakan oleh peneliti pada bulan Januari hingga Februari 2020 kelas IV UPT SD Negeri 067775 Medan Johor. Kegiatan pembelajaran masih di dominasi oleh aktivitas guru yang hanya mengajarkan menggunakan media buku paket siswa, media pembelajaran PKn masih kurang dan sangat jarang dipergunakan selama proses pembelajaran dan siswa tidak konsentrasi dalam mengikuti pembelajaran yang disebabkan oleh metode pembelajaran yang disampaikan oleh guru cenderung menggunakan metode ceramah pada saat pembelajaran berlangsung, penyediaan buku cetak juga tidak cukup sehingga membuat peserta didik tidak paham akan materi, hal ini berdampak pada perilaku siswa yang terlihat cepat merasa bosan, tidak tertarik dalam mengikuti pembelajaran dan membuat siswa tidak semangat dalam belajar, siswa kurang optimal dalam belajar karena hanya tersedia media buku paket cetak saja, serta belum adanya pengembangan media pembelajaran lainnya yang digunakan oleh guru.

Kenyataan lainnya pada saat guru mengajar pada pembelajaran PKn guru belum maksimal dalam menggunakan media pembelajaran, keadaan di kelas tidak kondusif, siswa tidak fokus serta kurang tertarik dalam mengikuti pembelajaran, siswa juga tidak sepenuhnya memperhatikan guru saat guru menerangkan dikarenakan bosan dengan aktivitas mendengarkan, kemudian mencari kesibukan lain dengan mengganggu temannya. menyebabkan banyak siswa yang tidak mengetahui bunyi pancasila serta lambang sila pancasila, karena siswa menganggap pembelajaran PKn susah untuk diingat dan kurang menyenangkan bagi siswa.

Sedangkan, ketika guru mulai untuk menggunakan media pembelajaran berupa gambar lambang pancasila yang dicocokkan dengan bunyi sila pancasila sebagai pendukung, siswa terlihat antusias dan aktif dalam mengikuti pembelajaran serta suasana kelas berubah menjadi kondusif. Hal ini karena media yang diberikan oleh guru membuat siswa tertarik, siswa juga merasakan hal yang baru dalam kegiatan pembelajaran dan mengakibatkan siswa lebih tertarik dalam mengikuti pembelajaran dengan menggunakan media pembelajaran. Pada kenyataannya, sesuatu hal yang baru akan membuat siswa merasa tertarik dan memotivasi diri untuk mencari tahu hal yang baru tersebut. Apalagi hal yang baru tersebut dibuat dengan semenarik mungkin, maka akan membuat siswa untuk lebih mempelajarinya dan dapat menjadi pengalaman khusus pada peserta didik.

Berdasarkan hal tersebut, cara yang dapat di tempuh guru untuk meningkatkan kegiatan pembelajaran yaitu perlu adanya media pembelajaran PKn yang dapat menarik perhatian siswa, menambah semangat belajar siswa, 
dan memudahkan siswa dalam memahami materi. Salah satu media yang dapat menarik perhatian belajar siswa, dan merangsang ketertarikan dalam materi Pancasila pada pembelajaran PKn adalah media Pop Up Book. Media Pop Up Book dirasa peneliti efektif jika diterapkan pada pembelajaran PKn karena selain menarik dan tampilan gambar yang berbentuk tiga dimensi, Media Pop Up Book juga memiliki kelebihan yaitu dengan kegiatan seperti membuka, melipat, bergerak, dan menggeser bagian Pop Up Book sehingga memberikan kejutan dan kekaguman bagi peserta didik ketika membuka setiap halamannya. Kegiatan tersebut memberi kesan bagi peserta didik sehingga materi akan mudah masuk ke dalam ingatan ketika menggunakannya. Pop Up Book adalah sebuah buku yang memiliki bagian yang bergerak atau memiliki unsur 3 dimensi serta memberikan visualisasi cerita menarik, mulai dari tampilan gambar yang dapat bergerak ketika halamannya dibuka, Pop Up Book dapat menambah semangat belajar siswa serta dapat menggunakan media secara mandiri maupun kelompok.

Berdasarkan uraian di atas, maka peneliti mengembangkan media pembelajaran Pop Up Book untuk peserta didik tingkat sekolah dasar agar peserta didik lebih tertarik, tidak mudah bosan dengan kegiatan belajar mengajar dan memudahkan peserta didik untuk memahami materi yang diajarkan oleh guru. Pada media pembelajaran Pop Up Book tersebut disajikan dengan warna-warna menarik dan tulisan-tulisan yang mendukung media tersebut, dan tentunya mencakup materi sesuai dengan KD secara ringkas dan efektif. Peneliti berharap dengan mengembangkan suatu media pembelajaran yang menarik yaitu berupa Pop Up Book dapat dijadikan sebagai salah satu solusi yang peneliti lakukan dalam mengatasi permasalahan di kelas pada pembelajaran muatan PKn.

Berdasarkan latar belakang masalah diatas, maka penulis akan melakukan penelitian dengan judul "Pengembangan Media Pop Up Book pada Pembelajaran PKn di SD".

\section{METODE PENELITIAN}

Waktu penelitian pengembangan produk berupa Media Pop Up Book pada Pembelajaran PKn di SD Negeri 067775 Medan Johor yang digunakan untuk penelitian ini yaitu pada bulan Juli 2021. Desain penelitian pada media pembelajaran berupa Pop Up Book ini menggunakan penelitian dan pengembangan R\&D (Research and Development). Penelitian pengembangan adalah metode penelitian yang bertujuan untuk menghasilkan suatu produk dan menguji apakah produk tersebut layak digunakan atau tidak berdasarkan penilaian dari para ahli/pakar melalui tahap validasi. (Sugiyono, 2017: 3-5). 
Ability : Journal of Education and Social Analysis

Volume 2, Issue 4, Oktober 2021

Page : 110-122

Sedangkan menurut Endang Mulyatiningsih, (2013: 161) mengatakan penelitian dan pengembangan (R\&D) bertujuan untuk menghasilkan produk baru melalui beberapa proses pengembangan. Produk yang dihasilkan dalam Penelitian dan Pengembangan (R\&D) bisa berupa media, modul, buku, alat evaluasi, dan perangkat pembelajaran.

Pada pengembangan media Pop Up Book ini peneliti akan menggunakan model penelitian dan pengembangan (R\&D) dengan model 4D yang merupakan perpanjangan dari Define (Pendefinisian), Design (Perancangan), Development (Pengembangan) dan Dissemination (Diseminasi) yang dikembangkan oleh Thiagarajan (1974), (Sugiyono, 2017: 37-38). Adapun menurut Endang Mulyatiningsih, (2013: 161) menyatakan terdapat empat tahap dalam pengembangan media pembelajaran dengan model 4D Thiagarajan, akan tetapi dalam pelaksanaannya dalam penelitian ini di modifikasi menjadi 3D yaitu Define (Pendefinisian), Design (Perancangan), Development (Pengembangan).

\section{HASIL PENELITIAN DAN PEMBAHASAN}

Penelitian ini merupakan penelitian pengembangan Research and Development (R\&D), Penelitian ini menghasilkan suatu produk media Pop Up Book materi pancasila pada pembelajaran PKn. Pengembangan media Pop Up Book ini dikembangkan bedasarkan model pengembangan 4D yang dikembangkan oleh Thiagarajan (1974) yang terdiri dari empat tahap yaitu, (1) Define (pendefinisian), (2) Design (Perancangan), (3) Development (pengembangan) dan (4) Disseminate (penyebaran). Pada teori yang telah peneliti jelaskan di bab III peneliti telah memodifikasi model pengembangan 4D menjadi 3D. Dinyatakan bahwa pada tahap ini dilakukan hanya sampai pada tahap Development (pengembangan). Karena rumusan masalah pada penelitian ini hanya sebatas Layak atau Tidak Layaknya media Pop Up Book yang dikembangkan. Jadi karena alasan inilah peneliti tidak melakukan disseminate (penyebaran).

Pengembangan media dilakukan dalam beberapa tahap. Pada tahap awal peneliti memilih materi dengan berpedoman pada Kompetensi Inti (KI), Kompetensi Dasar (KD), Indikator dan buku pelajaran kelas IV semester 1. Setelah memilih materi yang akan dikembangkan dengan membuat desain media pembelajaran Pop Up Book. Pop Up Book yang telah di rancang atau di desain kemudian dicetak (Print). Selanjutnya dipotong, ditempel dan dilipat yang selanjutnya di bentuk atau di rangkai sesuai teknik Pop Up yang digunakan. Media pembelajaran Pop Up Book yang sudah selesai dirangkai 
Ability : Journal of Education and Social Analysis

Volume 2, Issue 4, Oktober 2021

Page : 110-122

kemudian dilakukan validasi oleh 3 validator yakni ahli materi yaitu dosen, ahli media yaitu dosen dan ahli Pembelajaran yaitu respon guru kelas IV.

Hasil validasi oleh ahli materi memperoleh penilaian terhadap aspek kesesuaian materi dengan KD meliputi kesesuaian materi pancasila dengan kompetensi dasar dan indikator yang akan dicapai siswa menunjukkan tanggapan penilaian "ya" (baik), materi makna pancasila di ambil dari buku guru dan buku siswa kelas III SD kurikulum 2013 revisi 2018. Materi sesuai dengan tujuan pembelajaran menunjukkan tanggapan penilaian "ya" (baik) dan materi yang disajikan dapat mencapai tujuan pembelajaran menunjukkan tanggapan penilaian "ya" (baik). Penilaian terhadap aspek keakuratan materi meliputi materi yang disajikan dalam media Pop Up Book sesuai dengan kurikulum menunjukkan tanggapan penilaian "ya" (baik), kebenaran konsep/materi pancasila dalam pembelajaran menunjukkan tanggapan penilaian "ya" (baik), materi pancasila di ambil berdasarkan buku guru dan buku siswa kelas III SD kurikulum 2013 revisi 2018. Urutan penyajian materi pancasila dalam pembelajaran menunjukkan tanggapan penilaian "ya" (baik), materi pancasila di urutkan dari KI, KD, penjelasan umum tentang pancasila, makna dari setiap simbol sila-sila pancasila, butir-butir sila pancasila serta contohnya dan materi pada media Pop Up Book relevan dengan materi yang harus dipelajari menunjukkan tanggapan penilaian "ya" (baik). Penilaian aspek kemutakhiran materi meliputi kegiatan yang disajikan dalam media yang dikembangkan dapat menumbuhkan rasa ingin tahu siswa menunjukkan tanggapan penilaian "ya" (baik), dengan adanya media Pop Up Book yang dikembangkan akan membuat proses pembelajaran semakin menarik dan dapat menumbuhkan rasa ingin tahu siswa. Kemudahan dalam memahami materi pancasila dalam pembelajaran menunjukkan tanggapan penilaian "ya" (baik), materi pancasila yang di sajikan di sesuaikan dengan tingkat pemahaman siswa berdasarkan karateristik siswa dalam memahami pembelajaran dan keruntutan materi pembelajaran sesuai dengan alur pikir peserta didik menunjukkan tanggapan penilaian "ya" (baik). Penilaian aspek kesesuaian dengan perkembangan peserta didik meliputi materi pada media Pop Up Book sudah sesuai dengan tingkat perkembangan peserta didik menunjukkan tanggapan penilaian "ya" (baik), dengan menggunakan media Pop Up Book siswa lebih mudah memahami materi yang disampaikan menunjukkan tanggapan penilaian "ya" (baik), kesesuaian materi pembelajaran dengan tingkat kemampuan peserta didik menunjukkan tanggapan penilaian "ya" (baik), adanya interaksi langsung media dengan peserta didik menunjukkan tanggapan penilaian "ya" (baik) dan penyampaian materi pada media menarik untuk dipahami oleh siswa menunjukkan tanggapan penilaian 
Ability : Journal of Education and Social Analysis

Volume 2, Issue 4, Oktober 2021

Page : 110-122

"ya" (baik). Penilaian aspek kesesuaian dengan perkembangan peserta didik meliputi materi pada media Pop Up Book sudah sesuai dengan tingkat perkembangan peserta didik menunjukkan tanggapan penilaian "ya" (baik), dengan menggunakan media Pop Up Book siswa lebih mudah memahami materi yang disampaikan menunjukkan tanggapan penilaian "ya" (baik), kesesuaian materi pembelajaran dengan tingkat kemampuan peserta didik menunjukkan tanggapan penilaian "ya" (baik), adanya interaksi langsung media dengan peserta didik menunjukkan tanggapan penilaian "ya" (baik), dan Penyampaian materi pada media menarik untuk dipahami oleh siswa, menunjukkan tanggapan penilaian "ya" (baik). Penilaian aspek tampilan dan bahasa meliputi penggunaan gambar desain media Pop Up Book tepat dengan materi menunjukkan tanggapan penilaian "ya" (baik), penggunaan warna pada media Pop Up Book menarik untuk siswa menunjukkan tanggapan penilaian "ya" (baik), berbagai macam warna yang cerah menjadi pilihan dalam membuat media Pop Up Book. Kesesuaian kalimat yang terdapat pada media mudah dipahami siswa menunjukkan tanggapan penilaian "ya" (baik), pemilihan kata dan kalimat harus sesuai dengan bahasa indonesia yang baik dan benar sesuai kaidah yang berlaku yang mudah di pahami oleh siswa dan kalimat yang digunakan pada media jelas sesuai dengan kaidah Bahasa Indonesia menunjukkan tanggapan penilaian "ya" (baik). Dengan masukan validator yaitu "Media ini menarik dan menjadi media Pembelajaran/Pendidikan Dasar. Media ini layak untuk dipergunakan saat proses belajar mengajar di Sekolah" dengan demikian media Pop Up Book pada materi Pancasila menunjukkan kriteria Valid atau Layak.

Hasil validasi oleh ahli media memperoleh penilaian terhadap aspek tampilan desain media Pop Up Book meliputi media menggambarkan isi/materi ajar yang sesuai dengan ilustrasi kehidupan sehari-hari menunjukkan tanggapan penilaian "ya" (sangat baik), tampilan gambar media Pop Up Book memberikan kesan positif sehingga mampu menarik perhatian siswa untuk belajar menunjukkan tanggapan penilaian "ya" (sangat baik), gambar yang dipilih dalam media Pop Up Book selain sesuai dengan materi pancasila juga dapat memberikan kesan positif kepada siswa. Warna yang digunakan pada media sangat sesuai kontraks antara satu dengan yang lainnya menunjukkan tanggapan penilaian "ya" (sangat baik), gambar yang digunakan pada media jelas dan sesuai dengan kebutuhan siswa menunjukkan tanggapan penilaian "ya" (sangat baik), warna tampilan dan background yang digunakan pada media kombinasi warna yang menarik menunjukkan tanggapan penilaian "ya" (sangat baik), warna tampilan dan background media Pop Up Book di buat semenarik mungkin agar siswa tidak merasa bosan saat mengikuti 
Ability : Journal of Education and Social Analysis

Volume 2, Issue 4, Oktober 2021

Page : 110-122

pembelajaran dan jenis huruf yang digunakan pada media terlihat jelas dan terbaca menunjukkan tanggapan penilaian "ya" (sangat baik). Penilaian aspek bahasa meliputi menggunakan Bahasa Indonesia yang sesuai dengan Ejaan yang Disempurnakan (EYD) menunjukkan tanggapan penilaian "ya" (sangat baik), Bahasa Indonesia merupakan bahasa persatuan, bahasa yang di gunakan menggunakan EYD yang mudah di pahami oleh siswa. Kalimat yang digunakan pada media mudah dipahami siswa menunjukkan tanggapan penilaian "ya" (sangat baik) dan kesantunan penggunaan bahasa menunjukkan tanggapan penilaian "ya" (sangat baik), selain bahasa yang sesuai dengan Ejaan Yang Disempurnakan (EYD) dan sesuai dengan karateristik siswa juga sangat penting memilih bahasa yang santun dan pembelajaran. Penilaian aspek media dalam pembelajaran meliputi kesesuaian dari penyajian gambar dan materi yang dibahas menunjukkan tanggapan penilaian "ya" (sangat baik), penyajian media Pop Up Book dilakukan secara runtut menunjukkan tanggapan penilaian "ya" (sangat baik), media Pop Up Book yang di kembangkan di buat sesuai urutan materi makna pancasila. Penyajian media Pop Up Book mendukung siswa untuk terlibat dalam pembelajaran menunjukkan tanggapan penilaian "ya" (sangat baik), dengan adanya media Pop Up Book siswa dapat memanfaatkan Pop Up Book untuk interaktif karena terdapat bagian-bagian yang menuntut peranan siswa. Media Pop Up Book yang dikembangkan menarik dan mudah digunakan dalam pembelajaran PKn di SD menunjukkan tanggapan penilaian "ya" (sangat baik), media yang dikembangkan dapat digunakan sebagai alternatif pembelajaran menunjukkan tanggapan penilaian "ya" (sangat baik) dan kemampuan media Pop Up Book yang dikembangkan dapat menumbuhkan rasa ingin tau siswa dan dapat menciptakan semangat belajar peserta didik menunjukkan tanggapan penilaian "ya" (sangat baik). Dengan masukan validator yaitu "Media Pop Up Book dengan materi Pancasila yang dikembangkan oleh mahasiswa bernama Erica sudah Sangat Layak untuk diterapkan sebagai langkah awal mencari tahu efektivitas media tersebut terhadap pemahaman Pancasila oleh peserta didik di tingkat SD" dengan demikian media Pop Up Book pada materi Pancasila menunjukkan kriteria Valid atau Sangat Layak.

Hasil validasi oleh ahli pembelajaran yaitu respon guru kelas IV memperoleh penilaian terhadap aspek penyajian materi media Pop Up Book meliputi kesesuaian materi pada media dengan materi pokok dalam kompetensi Dasar menunjukkan tanggapan penilaian "ya" (sangat baik), materi pancasila di ambil dari buku guru dan buku siswa kelas III SD kurikulum 2013 revisi 2018. Kesesuaian materi yang disajikan pada media Pop Up Book dengan tujuan pembelajaran menunjukkan tanggapan penilaian "ya" (sangat baik), 
Ability : Journal of Education and Social Analysis

Volume 2, Issue 4, Oktober 2021

Page : 110-122

materi pancasila telah sesuai dengan rumusan tujuan pembelajaran yang akan di capai. Kemudahan media Pop Up Book untuk memahami materi yang disajikan menunjukkan tanggapan penilaian "ya" (sangat baik), media Pop Up Book di kembangkan semenarik mungkin untuk menarik minat siswa untuk pengikuti pembelajaran materi pancasila. Materi yang disajikan dalam media sesuai dengan tingkat kemampuan siswa menunjukkan tanggapan penilaian "ya" (sangat baik), materi pancasila di pilih sesuai dengan kriteria berpikir anak kelas III SD dan media pembelajaran Pop Up Book materi pancasila mudah dipahami dan berkaitan dengan kehidupan sehari-hari menunjukkan tanggapan penilaian "ya" (sangat baik), media Pop Up Book menggunakan gambar yang menggambarkan kehidupan sehari-hari agar peserta didik lebih mudah memahami materi pancasila. Penilaian aspek tampilan media Pop Up Book meliputi media Pop Up Book menggunakan kalimat yang mudah dipahami peserta didik menunjukkan tanggapan penilaian "ya" (sangat baik), kalimat pada media Pop Up Book di ringkas sangat sederhana agar siswa lebih memahami materi yang sedang di pelajari yaitu materi pancasila. Kemenarikan tampilan media Pop Up Book untuk dipelajari oleh peserta didik menunjukkan tanggapan penilaian "ya" (sangat baik), media Pop Up Book di kembangkan semenarik mungkin untuk menarik minat siswa untuk belajar. Kejelasan tulisan pada media Pop Up Book menunjukkan tanggapan penilaian "ya" (sangat baik), ukuran tulisan pada media Pop Up Book di pilih tidak terlalu kecil dan tidak terlalu besar, jelas dan tidak membuat bingung siswa saat membaca. Penyajian gambar media Pop Up Book menarik perhatian siswa untuk belajar menunjukkan tanggapan penilaian "ya" (sangat baik), gambar pada media Pop Up Book di pilih semenarik mungkin agar menarik minat siswa untuk belajar serta sesuai dengan materi yang akan di pelajari. Penggunaan gambar desain media Pop Up Book tepat dengan materi menunjukkan tanggapan penilaian "ya" (sangat baik) dan warna tampilan dan baground pada media pembelajaran Pop Up Book kombinasi warna yang menarik dan jelas menunjukkan tanggapan penilaian "ya" (sangat baik), warna tampilan dan background media Pop Up Book di buat semenarik mungkin agar siswa tidak merasa bosan saat mengikuti pembelajaran. Penilaian aspek keterlibatan peserta didik dalam menggunakan media meliputi media yang dikembangkan membuat siswa lebih aktif dalam mengikuti kegiatan pembelajaran menunjukkan tanggapan penilaian "ya" (sangat baik), siswa juga dapat memanfaatkan media Pop Up Book untuk interaktif karena ada bagian-bagian yang menuntut peranan siswa dalam menggunakan media Pop Up Book. Kemampuan media mengaktifkan peserta didik dalam pembelajaran menunjukkan tanggapan penilaian "ya" (sangat baik), kemampuan media 
Ability : Journal of Education and Social Analysis

Volume 2, Issue 4, Oktober 2021

Page : 110-122

menciptakan rasa senang peserta didik dalam pembelajaran menunjukkan tanggapan penilaian "ya" (sangat baik), dengan tampilan gambar yang berbentuk tiga dimensi ketika halamannya dibuka gambar tampak berdiri membuat siswa merasa senang dan bersemangat dalam mengikuti pembelajaran dan kemampuan media menciptakan rasa semangat peserta didik menunjukkan tanggapan penilaian "ya" (sangat baik). Dengan masukan validator yaitu "Media Pop Up Book dengan materi Ayo Mengamalkan Pancasila yang dikembangkan oleh Erica sudah sangat layak dan dapat diterapkan sebagai langkah awal untuk proses belajar mengajar di Sekolah". Dengan demikian media Pop Up Book pada materi Pancasila menunjukkan kriteria Valid atau Sangat Layak.

Keberhasilan ini tidak terlepas dari berbagai manfaat dan kelebihan yang dimiliki oleh media Pop Up Book. Media Pop Up Book memiliki berbagai manfaat dalam proses kegiatan belajar mengajar. Berdasarkan pendapat Dzuanda (dalam Dewanti dkk, 2018: 222), media Pop Up Book memiliki berbagai manfaat yang sangat berguna, yaitu: Mengajarkan anak untuk lebih menghargai buku dan merawatnya atau memperlakukannya dengan lebih baik sehingga anak menjaga buku yang dimilikinya dengan baik tanpa ada paksaan. Mengembangkan kreatifitas anak. Merangsang imajinasi anak. Menambah pengetahuan serta memberi pengenalan bentuk benda. Dapat digunakan sebagai media untuk menumbuhkan motivasi dan menanamkan kecintaan anak terhadap membaca.

Media Pop Up Book salah satu strategi dalam pembelajaran karena efektif dan interaktif dalam kegiatan pembelajaran, menggambarkan secara visual, membantu siswa dalam memberikan pengalaman mengenai lingkungan sekitar, menambah pengalaman baru dalam aktivitas sehari-hari, dan memberikan kesempatan bagi siswa berpartisipasi dalam kegiatan belajar mengajar dengan menggunakan media Pop Up Book.

Berdasarkan pembahasan di atas dapat disimpulkan bahwa produk media Pop Up Book materi pancasila pada pembelajaran PKn di SD yang di kembangkan peneliti dinyatakan Valid atau Sangat Layak dan tidak terdapat revisi oleh para ahli, dan media Pop Up Book yang telah di kembangkan sangat layak digunakan sebagai bahan ajar dalam pembelajaran. Dengan adanya media Pop Up Book yang menarik dan materi yang dapat divisualisasikan dapat menjadikan proses pembelajaran lebih efektif, lebih semangat dalam belajar dan sangat membantu dalam penyampaian materi khususnya pembelajaran PKn, dan media pembelajaran Pop Up Book bersifat konkret atau nyata dapat digunakan secara langsung. 
Ability : Journal of Education and Social Analysis

Volume 2, Issue 4, Oktober 2021

Page : 110-122

\section{KESIMPULAN}

Berdasarkan hasil penelitian dan pengembangan yang telah dilakukan oleh peneliti dapat disimpulkan bahwa penelitian dan pengembangan menggunakan tahapan-tahapan dengan model 4D yang dimodifikasi menjadi 3D dengan langkah-langkah (1) Define (Pendefinisian), (2) Design (Perancangan) dan (3) Development (Pengembangan) telah menghasilkan suatu produk berupa media Pop Up Book pada pembelajaran PKn di SD materi pancasila. Di dalam media Pop Up Book memiliki keunggulan yaitu selain menarik dengan tampilan gambar yang berbentuk tiga dimensi siswa juga dapat memanfaatkan penggunaan media Pop Up Book untuk interaktif seperti bagian-bagian yang menuntut peranan siswa dengan melibatkan siswa secara langsung menggunakan media Pop Up Book.

Berdasarkan kelayakan media dari masukan para ahli materi yaitu dosen, ahli media yaitu dosen dan ahli pembelajaran yaitu respon guru kelas IV. Dari data hasil validasi tersebut, maka pengembangan media Pop Up Book materi pancasila yang di kembangkan peneliti dinyatakan Sangat Layak digunakan sebagai bahan ajar dalam proses pembelajaran.

\section{REFERENCES}

Devi, A.S., Maisaroh, S. (2017). “Pengembangan Media Pembelajaran Buku Pop-Up Wayang Tokoh Pandhawa Pada Mata Pelajaran Bahasa Jawa Kelas V SD". Jurnal PGSD Indonesia. Vol. 3, (2), h. 12.

Dewanti, H., Toenlioe, A.J.E., Soepriyanto, Y. (2018). "Pengembangan Media PopUp Book Untuk Pembelajaran Lingkungan Tempat Tinggalku Kelas IV SDN 1 Pakunden Kabupaten Ponorogo". Jurnal Kajian Teknologi Pendidikan. Vol. 1, (3), h. 222-223.

Endang, Mulyatiningsih, 2013. Metode Penelitian Terapan Bidang Pendidikan. Bandung: Alfabeta.

Gultom, T. (2020). Penilaian Kinerja Guru Mengenai Profesionalisme Guru Di Smp Negeri 2 Pangaribuan Kabupaten Tapanuli Utara Tahun 2020. Journal Of Education And Teaching Learning (JETL), 2(3), 29-43. https://doi.org/10.51178/jetl.v2i3.66

Gurning, B., Lubis, E.A. 2017. Strategi Belajar Mengajar. Yogyakarta:

K-Media.

Hidayah, N., Ulva K.R. (Juni 2017). “Pengembangan Media Pembelajaran Berbasis Komik Pada Mata Pelajaran Ilmu Pengetahuan Sosial Kelas IV MI Nurul Hidayah Roworejo Negrikaton Pesawaran". Jurnal Terampil. Vol. 4, (1), h. 3. Istirani \& Pulungan, I. 2018. Ensiklopedia Pendidikan. Medan: Media Persada. Johannes, J. (2021). Meningkatkan Hasil Belajar Siswa Menggunakan Model 
Pembelajaran Make A Match Pada Pelajaran IPA Materi Sifat-Sifat Cahaya Di Kelas V SD Negeri 060952 Medan Labuhan T.P. 2019/2020. Journal Of Education And Teaching Learning (JETL), 3(1), 50-61. https://doi.org/10.51178/jetl.v3i1.123

Karisma, K.E., Margunayasa G., Tri Prasasti, P.A. (2020). “Media Pop-Up Book pada Topik Perkembangbiakan Tumbuhan dan Hewan Kelas VI Sekolah Dasar". Jurnal Ilmiah Sekolah Dasar. Vol. 4, (2), h. 123.

Khuloqo, I.E. 2017. Belajar Dan Pembelajaran. Yogyakarta: Pustaka Pelajar.

Kurniawati, N., Sartinah, E.P. (2016). “Pengaruh Metode Bercakap-Cakap Berbasis Media Pop Up Book Terhadap Kemampuan Berbicara Anak Kelompok A" Jurnal PAUD Teratai. Vol. 5, (3), h. 2.

Lubis, M.A. 2018. Pembelajaran PPKn dalam Teori Pengajaran Abad 21 di SD/MI. Yogyakarta: Samudra Biru.

Lumbangaol, T. (2020). Penerapan Strategi Pembelajaran Mind Mapping Untuk Meningkatkan Hasil Belajar Siswa Pada Materi "Teks Panjang" Mata Pelajaran Bahasa Indonesia di SDN 173346 Dolok Martumbur Kecamatan Muara Kelas IV T.P 2018/2019. Journal Of Education And Teaching Learning (JETL), 2(2), 27-34. https://doi.org/10.51178/jetl.v2i2.62

Mariastutik, Z. (2015). "Pengembangan Alternasi Pembelajaran Ppkn melalui Modul Berbasis Kecakapan Sosial (Social Skills)". Jurnal Pendidikan Pancasila dan Kewarganegaraan, Th. 28, (1), h. 68.

Masturah, E.D., Mahadewi, L.P.P., Simamora, A.H. (2018). "Pengembangan Media Pembelajaran Pop-Up Book Pada Mata Pelajaran Ipa Kelas III Sekolah Dasar". Jurnal EDUTECH Universitas Pendidikan Ganesha. Vol. 6, (2), h. 214.

Mudlofir, A., Rusydiyah, E.F. 2016. Desain Pembelajaran Inovatif Dari Teori Ke Praktik. Jakarta: Raja Grafindo Prasada.

Mujiyanti Hidayat, A.M., Hidayat, O.S., Satrio. (2019). “Pengembangan Media Pop-Up Book Peripanca Pada Pembelajaran Pendidikan Pancasila Dan Kewarganegaraan Sekolah Dasar Tema Tugasku Sehari-Hari Di Kelas II Sekolah Dasar". Jurnal Dinamika Sekolah Dasar. Vol. 1, (1).

Nurdyansyah. 2019. Media Pembelajaran Inovatif. Jawa Timur: UMSIDA Press

Pakpahan, A.F, etal. 2020. Pengembangan Media Pembelajaran: Yayasan Kita Menulis.

Pentium Satu, "Analisis Kelebihan Dan Kelemahan Pop up Sebagai Media Pembelajaran Bagi Anak Sekolah Dasar", http:// pentium1loadingselalu.blogspot.com/2016/10/analisis-elebihandan-kelemahanpop-up.html (diakses 06 Februari 2021)

Peraturan Menteri Pendidikan Nasional Nomor 22 Tahun 2006. 
Ability : Journal of Education and Social Analysis

Volume 2, Issue 4, Oktober 2021

Page : 110-122

Rahmawati, Diyah. 2017. "Pengembangan Media Pembelajaran Pop Up Book Pada Materi Perubahan Wujud Benda Untuk Siswa SDLB Tunarungu Kelas IV". Skripsi. Fakultas Ilmu Pendidikan. Universitas Negeri Yogyakarta.

Safri, M., Sari. S.A., Marlina. (2017). "Pengembangan Media Belajar Pop-Up Book Pada Materi Minyak Bumi". Jurnal Pendidikan Sains Indonesia. Vol. 5, (1), h. 108.

Sholeh, M. (2019). "Pengembangan Media Pop-Up Book Berbasis Budaya Lokal Keberagaman Budaya Bangsaku Siswa Kelas IV Sekolah Dasar". JURNAL GENTALA PENDIDIKAN DASAR. Vol. 4, (1).

Siregar, A., Rahmah, E. (2016). “Model Pop Up Book Keluarga Untuk Mempercepat Kemampuan Membaca Anak Kelas Rendah Sekolah Dasar". Jurnal Ilmu Informasi Perpustakaan dan Kearsipan. Vol. 5, (1), h. 12.

Sukmadinata, N.S. 2010. Metode Penelitian Pendidikan. Bandung: PT Remaja Rosdakarya.

Sugiarti, L., Handayani, D.E. (2017). Pengembangan Media Pokari Pokabu (Pop-Up dan Kartu Ajaib Pengelompokkan Tumbuhan) Untuk Siswa Kelas III SD/MI. Jurnal Pendidikan Guru MI. Vol. 4, (1), h. 111.

Sugiyono. 2017. Metode Penelitian E Pengembangan (Research E Development).

Bandung: Penerbit Alfabeta.

Sylvia, I.N. \& Hariani, S. (2015). "Pengaruh Penggunaan Media Pop-Up Book terhadap Keterampilan Menulis Narasi Siswa Sekolah Dasar". Jurnal Pendidikan Guru Sekolah Dasar, Vol. 3, (2), h. 1198. 